\title{
Microarray profiling of gene expression patterns in glomerular cells of astaxanthin-treated diabetic mice: A nutrigenomic approach
}

\author{
YUJI NAITO $^{1}$, KAZUHIKO UCHIYAMA ${ }^{2}$, KATSURA MIZUSHIMA ${ }^{2}$, MASAAKI KURODA ${ }^{2}$, \\ SATOMI AKAGIRI ${ }^{2}$, TOMOHISA TAKAGI ${ }^{3}$, OSAMU HANDA ${ }^{3}$, SATOSHI KOKURA ${ }^{3}$, \\ NORIMASA YOSHIDA ${ }^{4}$, HIROSHI ICHIKAWA ${ }^{5}$, JIRO TAKAHASHI ${ }^{6}$ and TOSHIKAZU YOSHIKAWA ${ }^{1-3}$ \\ ${ }^{1}$ Department of Medical Proteomics, ${ }^{2}$ Inflammation and Immunology, ${ }^{3}$ Department of Biomedical Safety Science, \\ ${ }^{4}$ Molecular Gastroenterology and Hepatology, Graduate School of Medical Science, Kyoto Prefectural University of \\ Medicine, Kyoto 602-8566; ${ }^{5}$ Department of Food Sciences and Nutritional Health, The Faculty of Human Environment, \\ Kyoto Prefectural University, Kyoto 606-8522; ${ }^{6}$ Fuji Chemical Ind., Nakanikawa-gun, Toyama 930-0397, Japan
}

Received April 17, 2006; Accepted June 14, 2006

\begin{abstract}
We have demonstrated that astaxanthin reduces glomerular oxidative stress as well as inhibits the increase in urinary albumin in diabetic $\mathrm{db} / \mathrm{db}$ mice. The aim of the present study was to determine the gene expression patterns in the glomerular cells of the diabetic mouse kidney, and to investigate the effects of astaxanthin on the expression of these genes using a high-density DNA microarray. The diet administered to the astaxanthin-supplementation group was prepared by mixing a control powder with astaxanthin at a concentration of $0.02 \%$. Glomerular cells were obtained from the kidneys of mice by laser capture microdissection. Preparation of cRNA and target hybridization were performed according to the Affymetrix GeneChip eukaryotic small sample target labeling assay protocol. The gene expression profile was evaluated by the mouse expression set 430A GeneChip. Array data analysis was carried out using Affymetrix GeneChip operating and Ingenuity Pathway analysis software. Comparison between diabetic $\mathrm{db} / \mathrm{db}$ and non-diabetic $\mathrm{db} / \mathrm{m}$ mice revealed that 779 probes $(3.1 \%)$ were significantly affected, i.e. 550 probes were up-regulated, and 229 probes were down-regulated, both at levels of $\geq 1.5$-fold in the diabetic mice. Ingenuity signal analysis of 550 up-regulated probes revealed the mitochondrial oxidative phosphorylation pathway as the most significantly affected caronical pathway. The affected genes were associated with complexes I, III, and
\end{abstract}

Correspondence to: Dr Yuji Naito, Department of Medical Proteomics, Kyoto Prefectural University of Medicine, Kawaramachi-Hirokoji, Kamigyo-ku, Kyoto 602-8566, Japan E-mail: ynaito@koto.kpu-m.ac.jp

Key words: Astaxanthin, GeneChip, glomerular cells, nutrigenomics, oxidative phosphorylation, oxidative stress
IV located on the mitochondrial inner membrane, and the expression levels of these genes were decreased in mice treated with astaxanthin as compared to the levels in the control mice. In addition, the expression of many genes associated with oxidative stress, collagen synthesis, and transforming growth factor- $\beta$ signaling was enhanced in the diabetic mice, and this enhancement was slightly inhibited in the astaxanthin-treated mice. In conclusion, this genomewide nutrigenomics approach provided insight into genes and putative genetic pathways that are thought to be affected by stimulation by high-glucose concentrations. In addition, the present approach may help us gain a better understanding of the genes and pathways involved in the anti-diabetic mechanism of astaxanthin.

\section{Introduction}

It has been postulated that increased oxidative stress by high glucose concentrations in the blood is important in the pathogenesis of diabetic nephropathy. Studies using natural and synthetic antioxidants have provided convincing evidence that glomerular hypertrophy and the accumulation of collagen and transforming growth factor- $\beta$ (TGF- $\beta$ ) due to high glucose concentrations are largely mediated by reactive oxygen species (1-4). Kaneko and colleagues (1) have reported that antioxidant treatment $(\mathrm{N}$-acetyl-L-cysteine, vitamins $\mathrm{C}$ and $\mathrm{E}$ ) can exert beneficial effects on $\mathrm{db} / \mathrm{db}$ mice, with the preservation of in vivo $\beta$-cell function. It has also been reported that antioxidant treatment with vitamin $\mathrm{E}$, probucol, $\alpha$-lipoic acid, or taurine normalized not only diabetes-induced renal disorders such as albuminuria and glomerular hypertension, but also various types of glomerular pathology (3). It is thought that such studies might provide further insight into therapeutic strategies for treating patients with diabetes mellitus.

Astaxanthin, a common red-colored pigment found in algae, fish, and birds, is a carotenoid that exerts many highly potent pharmacological effects, including antioxidative 
activity $(5,6)$. Astaxanthin is reported to be more effective than other antioxidants such as vitamin $E$ and $\beta$-carotene in the prevention of lipid peroxidation in solution and in various biomembrane systems. In 2002, we first reported the potential usefulness of astaxanthin treatment for reducing glucose toxicity using $\mathrm{db} / \mathrm{db}$ mice, a rodent model of type 2 diabetes (7). The ability of islet cells to secrete insulin was determined by the glucose tolerance test, and this ability was found to be preserved in an astaxanthin-treated group, although a histological study of the pancreas revealed no significant differences in the B-cell mass between astaxanthin-treated and -untreated $\mathrm{db} / \mathrm{db}$ mice (7). Using the same model of diabetic mice, we recently demonstrated that astaxanthin treatment significantly ameliorates diabetic nephropathy, which is detemined based on urinary albumin levels and histological findings (8). In addition, it was clearly observed that longterm oral treatment with astaxanthin reduced not only the increased albuminuria otherwise observed in untreated diabetic mice but also ameliorated such an increase in the urinary excretion of 8-hydroxydeoxy-guanosine (8-OHdG) and in $8-\mathrm{OHdG}$ expression in the mesangial cells with little effect on blood glucose levels (8). Furthermore, our data demonstrated that the esterified astaxanthin used in our previous study was effectively absorbed and was transported successfully to the kidneys (8). Taken together, these results suggested that astaxanthin might directly attenuate diabetic oxidative damage, although a slight decrease in blood glucose levels would also be expected to contribute to the attenuation of such oxidative damage.

In patients with diabetic nephropathy as well as in experimental animal models, various molecules associated with oxidative stress, collagen synthesis, and transforming growth factor- $\beta$ (TGF- $\beta$ ) have been reported to play important roles in the onset and aggravation of diabetic nephropathy $(9,10)$. The enhanced expression of these molecules, the abnormal regulation of cell signaling, and the genetic polymorphism of these genes may all contribute to dysregulated cell proliferation and to an enhanced expansion of the extracellular matrix in the renal glomerular region. Many studies on the pathogenesis of diabetic nephropathy have been based on the analysis of the expression of a single molecule, or a relatively limited number of these molecules in diabetic glomerular cells. Recently, DNA microarray techniques have become available that have enabled the characterization of the mRNA expression pattern of a large number of genes simultaneously. In this study, we identified specific gene expression profiles in the renal glomerular cells of diabetic $\mathrm{db} / \mathrm{db}$ mice, and we investigated the effects of astaxanthin on the expression of these genes using a comprehensive GeneChip system analysis.

\section{Materials and methods}

Animals and experimental design. Six-week-old female $\mathrm{db} / \mathrm{db}$ mice, a rodent model of type 2 diabetes, and their nondiabetic $\mathrm{db} / \mathrm{m}$ littermates were purchased from the Clea Japan Co. Ltd. (Tokyo, Japan), and kept under controlled conditions with a 12 -h light/dark cycle at $21-25^{\circ} \mathrm{C}$. The mice were fed commercial CE-2 (Clea Japan) with free access to water for 1 week to adapt to the new environment. The CE-2 diet
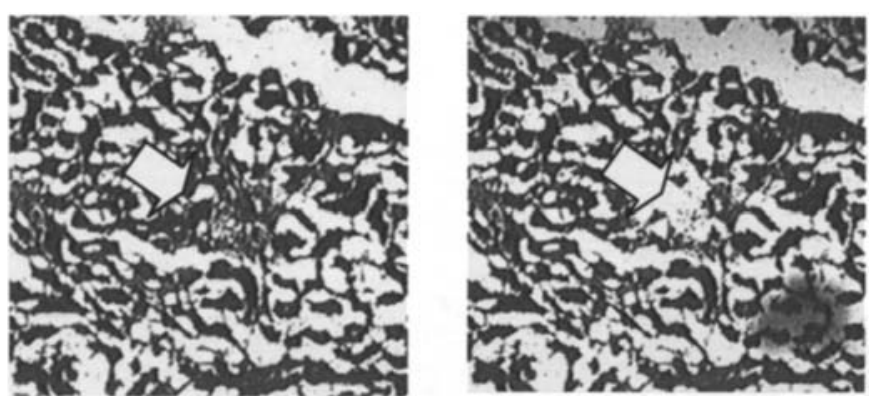

Figure 1. Laser capture microdissection. Renal glomerular cells were isolated by laser-assisted microdissection using an LM200 system. Left, before microdissection; right, after microdissection.

contained $(\mathrm{g} / 100 \mathrm{~g})$ : moisture 8.9 , protein 25.4 , fat 4.4 , fiber 4.1 , ash 6.9 , carbohydrates 50.3 , and sufficient vitamins and minerals to maintain the health of the mice. The mice were divided into three groups as follows: non-diabetic, $\mathrm{db} / \mathrm{m}$; diabetic, $\mathrm{db} / \mathrm{db}$; and diabetic $\mathrm{db} / \mathrm{db}$ treated with astaxanthin. Each of the groups contained 3 mice. The diet for the astaxanthin supplementation group was prepared by mixing CE-2 powder with astaxanthin (Fuji Chem. Industry Co. Ltd, Toyama, Japan) at $0.02 \%$. The food intake was measured daily for 6 weeks before dissection. The body weight of the mice was measured every 7 days. Maintenance of the animals and experimental procedures were carried out in accordance with the guidelines of the US National Institutes of Health for the Use of Experimental Animals. The procedures were approved by the Animal Care Committee of the Kyoto Prefectural University of Medicine.

Laser capture microdissection, cRNA amplification, and GeneChip hybridization. We used laser-assisted microdissection to obtain cell-specific RNA. Renal glomerular cells were identified on cryostat sections $(8 \mu \mathrm{m})$ of specimens obtained from the kidneys of the mice, and the cells were isolated by laser-assisted microdissection using an LM200 system (Olympus, Tokyo, Japan) (Fig. 1). A sample containing several hundred cells was collected from each kidney. Although laser capture microdissection can be used to produce cell-specific RNA, this method is limited by the amount of RNA that can be realistically obtained from captured populations of cells, making it unlikely that the yield would be sufficient for the commonly used GeneChip assay. To overcome this obstacle, our experiments were performed according to the Affymetrix GeneChip Eukaryotic small sample target labeling assay protocol (version II). Using this protocol, we succeeded in obtaining a sufficient amount of biotinylated cRNA to perform the GeneChip analysis from the small amount of renal glomerular cells obtained by laser captured microdissection.

The total RNA was extracted using a Qiagen RNeasy kit (Qiagen, Valencia, CA) and was treated with DNase1 (DNase1 kit, Qiagen) to remove any residual genomic DNA. Briefly, for the first-strand cDNA synthesis, the total RNA sample $(1 \mu 1)$, mixed with T7-Oligo(dT) promoter primer $(5 \mu \mathrm{M}, 1 \mu \mathrm{l})$, was incubated at $70^{\circ} \mathrm{C}$ in a thermal cycler for 6 min, cooled to $4^{\circ} \mathrm{C}$ for $2 \mathrm{~min}$, and was reverse-transcribed for $1 \mathrm{~h}$ at $42^{\circ} \mathrm{C}$ with $3 \mu \mathrm{l}$ of the RT Premix 1 [1.5 $\mu \mathrm{l}$ DEPC- 
treated water, $4 \mu 15 \mathrm{X}$ first-strand buffer, $2 \mu 1 \mathrm{DTT}(0.1 \mathrm{M})$, $1.5 \mu 1 \mathrm{dNTP} \operatorname{mix}(10 \mathrm{mM}), 1 \mu \mathrm{l}$ RNase inhibitor (40 U/ $\mu \mathrm{l})$, and $2 \mu 1$ SuperScript II $(200 \mathrm{U} / \mu 1)]$. The sample was then heated at $70^{\circ} \mathrm{C}$ for $10 \mathrm{~min}$ to inactivate the SuperScript II, and was cooled to $4^{\circ} \mathrm{C}$. Second-strand cDNA synthesis was carried out by adding $32.5 \mu 1$ of SS Premix 1 [91 $\mu 1$ DEPCtreated water, $30 \mu 15 \mathrm{X}$ second strand buffer, $3 \mu 1 \mathrm{dNTP}$ mix (10 mM), $1 \mu 1$ E. coli DNA ligase $(10 \mathrm{U} / \mu 1), 4 \mu 1$ E. coli DNA polymerase I (10 U/ $/ \mu \mathrm{l})$, and $1 \mu \mathrm{RNaseH}(2 \mathrm{U} / \mu \mathrm{l})]$ and incubating the sample for $2 \mathrm{~h}$ at $16^{\circ} \mathrm{C}$. The resulting cDNA was treated with $1 \mu 1 \mathrm{~T} 4 \mathrm{DNA}$ polymerase $(5 \mathrm{U} / \mu \mathrm{l})$ for $10 \mathrm{~min}$ at $16^{\circ} \mathrm{C}$, and was cleaned by ethanol precipitation. To perform in vitro transcription, the dried double-stranded cDNA pellet was mixed with the following reagents $(10 \mu \mathrm{l})$ : $4 \mu 1$ DEPC-treated water, $4 \mu 1$ premixed NTPs, $1 \mu 110 \mathrm{X}$ reaction buffer, and $1 \mu 110 \mathrm{X}$ enzyme mix, and the sample was incubated at $37^{\circ} \mathrm{C}$ in a water bath for $6 \mathrm{~h}$. The first-cycle cRNA was cleaned using the RNeasy mini protocol for RNA cleanup accompanying the RNeasy mini kit for cRNA purification (Qiagen, Valencia, CA). For the second cycle of amplification and labeling, the cRNA sample was mixed with random primers $(0.2 \mu \mathrm{g} / \mu \mathrm{l})$, incubated at $70^{\circ} \mathrm{C}$ for $10 \mathrm{~min}$, cooled on ice for $2 \mathrm{~min}$, and incubated at $42^{\circ} \mathrm{C}$ for $1 \mathrm{~h}$ with $5 \mu 1$ of the RT Premix 2 [5X first-strand buffer, DTT $(0.1 \mathrm{M})$, dNTP mix (10 mM), RNase inhibitor $(40 \mathrm{U} / \mu \mathrm{l})$, and SuperScript II $(200 \mathrm{U} / \mu \mathrm{l})]$. Second-strand cDNA synthesis was carried out by mixing the sample with $5 \mu \mathrm{M}$ T7Oligo(dT) promoter primer, incubating the resulting mixture at $70^{\circ} \mathrm{C}$ for $6 \mathrm{~min}$, cooling it at $4^{\circ} \mathrm{C}$, and re-incubating the sample with $62 \mu 1$ of SS Premix 2 [43.5 $\mu 1$ DEPC-treated water, $15 \mu 15 \mathrm{X}$ second strand buffer, $1.5 \mu 1 \mathrm{dNTP}$ mix (10 $\mathrm{mM})$, and $2 \mu 1 \mathrm{E}$. coli DNA polymerase I $(10 \mathrm{U} / \mu \mathrm{l})]$. The resulting cDNA was treated with $1 \mu \mathrm{l}$ T4 DNA polymerase (5 U/ $/ \mu 1$ ) for $10 \mathrm{~min}$ at $16^{\circ} \mathrm{C}$, and cleaned up by ethanol precipitation. To perform in vitro transcription and labeling with the ENZO BioArray high yield RNA transcript labeling kit, the dried double-stranded cDNA pellet was incubated at $37^{\circ} \mathrm{C}$ for $4 \mathrm{~h}$ with $40 \mu \mathrm{l}$ of the following reagents: $22 \mu \mathrm{l}$ DEPC-treated water, $4 \mu 1$ 10X HY reaction buffer, $4 \mu 1$ 10X biotin labeled ribonucleotides, $4 \mu 1$ 10X DTT, $4 \mu 1$ 10X RNase inhibition mix, and $2 \mu 120 \mathrm{X}$ T7 RNA polymerase. Labeled cRNA target was cleaned using RNeasy columns. The fragmentation, hybridization, washing, and staining were carried out according to the instructions described in the GeneChip expression analysis technical manual. Affymetrix GeneChip arrays (Affymetrix, Santa Clara, CA) were hybridized with the biotinylated products ( $5 \mu \mathrm{g} / \mathrm{chip})$ for $16 \mathrm{~h}$ at $45^{\circ} \mathrm{C}$ using the manufacturer's hybridization buffer. After washing the arrays, hybridized RNA was detected by staining the sample with streptavidin-phycoerythrin (6X SSPE, $0.01 \%$ Tween-20, pH 7.6, $2 \mathrm{mg} / \mathrm{ml}$ acetylated bovine serum albumin, and $10 \mu \mathrm{g} / \mathrm{ml}$ of streptavidin-phycoerythrin from Molecular Probes). The DNA chips were scanned using a specially designed confocal scanner (GeneChip Scanner 3000, Affymetrix).

Data analysis. Array data analysis was carried out using Affymetrix GeneChip operating software (GCOS) version 1.0. GCOS analyzes image data and computes an intensity value for each probe cell. Briefly, mismatch probes act as specificity controls that allow the direct subtraction of both background and cross-hybridization signals. To determine the quantitative RNA abundance, the average difference values (i.e., gene expression levels) representing the perfect matchmismatch for each gene-specific probe family was calculated, and the fold changes in average difference values were determined according to Affymetrix algorithms and procedures as follows: I, increase; MI, marginal increase; D, decrease; $\mathrm{MD}$, marginal decrease; and $\mathrm{NC}$, no change. For the pathway analysis, gene probe set ID numbers were imported into the Ingenuity pathway analysis software (Ingenuity Systems, Mountain View, CA). The identified genes were mapped to genetic networks available in the Ingenuity database and were then ranked by a score. The score is the probability that a collection of genes is equal to or greater than the number in a network that could be achieved by chance alone. A score of 3 indicates that there is a $1 / 1000$ chance $(p=0.001)$ that the focus genes randomly occur in a network. Therefore, gene sets with scores of $\geq 3$ have a $99.9 \%$ confidence level of not being randomly generated. This score was used as the cut-off for identifying gene networks significantly affected by indomethacin.

\section{Results and Discussion}

In the present study, we used a high-density oligonucleotide microarray technique for the mRNA expression profile of renal glomerular cells in order to investigate the mechanism of diabetic nephropathy and to clarify the effects of chronic treatment with astaxanthin on these changes in the levels of mRNA. We used the GeneChip of mouse expression array 430A (Affymetrix), which contained 22,690 probes representing $\sim 15,000$ full-length sequences and 4,000 EST clusters selected from the UniGene database. Comparison of the expression profiles from normal $\mathrm{db} / \mathrm{m}$ and diabetic $\mathrm{db} / \mathrm{db}$ mice, and from $\mathrm{db} / \mathrm{db}$ and astaxanthin-treated $\mathrm{db} / \mathrm{db}$ mice enabled the identification of differentially regulated genes associated with diabetic-induced hyperglycemia and activity of astaxanthin, respectively.

The present study showed that of the 22,690 probes examined, 779 (3.4\%) were up-regulated (550 probes) or down-regulated ( 229 probes) $\geq 1$.5-fold in the diabetic mice in comparison with the $\mathrm{db} / \mathrm{m}$ mice (Fig. 2). Tables I and II show $\geq 5.0$-fold up-regulation and down-regulation, respectively, of genes in the diabetic mice in comparison with those of the $\mathrm{db} / \mathrm{m}$ mice. Among the 550 up-regulated and 229 down-regulated probes in the diabetic mice, the expression levels of $520(94.5 \%)$ and 125 (54.5\%) probes, respectively, were reversed by treatment with astaxanthin. To further refine the list of diabetes-affected genes, our next goal was to identify the genes that are known to interact biologically. To this end, we used the pathway analysis tool (Ingenuity System) to carry out analyses of the 550 upregulated genes. Table III shows 6 genetic networks affected in the glomerular cells of diabetic mice, as defined by the pathway analysis tool. These networks describe functional relationships between gene products based on known interactions reported in the literature. These networks were associated with oxidative phosphorylation, the citrate cycle, ubiquinone biosynthesis, pyruvate metabolism, fatty acid 
Table I. Up-regulated genes in $\mathrm{db} / \mathrm{db}$ mice.

\begin{tabular}{|c|c|c|c|c|c|}
\hline \multirow[t]{2}{*}{ Probe set ID } & \multirow[t]{2}{*}{ Descriptions } & \multicolumn{2}{|c|}{ Average difference ${ }^{\mathrm{a}}$} & \multirow[t]{2}{*}{ Log ratio } & \multirow[t]{2}{*}{ Fold change ${ }^{b}$} \\
\hline & & $\mathrm{db} / \mathrm{db}$ & $\mathrm{db} / \mathrm{m}$ & & \\
\hline 1438634_x_at & LIM and SH3 protein 1 & 2695.1 & 10.3 & 8.0 & 256.00 \\
\hline 1433443_a_at & 3-hydroxy-3-methylglutaryl-coenzyme A synthase 1 & 6472.6 & 76.6 & 7.3 & 157.59 \\
\hline 1438610_a_at & Crystallin, $\zeta$ & 10955.2 & 95.5 & 7.1 & 137.19 \\
\hline 1423684_at & --- & 3573.7 & 43.8 & 7.0 & 128.00 \\
\hline 1415820_x_at & --- & 2286.4 & 18.0 & 6.8 & 111.43 \\
\hline \multirow[t]{2}{*}{ 1448382_at } & Enoyl-coenzyme A, hydratase/3-hydroxyacyl coenzyme & & & & \\
\hline & A dehydrogenase & 1482.1 & 27.9 & 6.7 & 103.97 \\
\hline 1455039_a_at & Transcriptional regulator, SIN3B (yeast) & 2383.9 & 23.7 & 6.7 & 103.97 \\
\hline 1456176_x_at & DNA segment, Chr 11, ERATO Doi 333, expressed & 6941.6 & 84.7 & 6.7 & 103.97 \\
\hline 1450387_s_at & --- & 11485.4 & 157.3 & 6.6 & 97.01 \\
\hline 1416180_a_at & Radixin & 1363.3 & 29.0 & 6.5 & 90.51 \\
\hline 1416633_a_at & $\begin{array}{l}\text { RIKEN cDNA 5730536A07 gene } \\
\text { tyrosine 3-monooxygenase/tryptophan 5- }\end{array}$ & 1771.9 & 14.7 & 6.5 & 90.51 \\
\hline 1426385_x_at & Monooxygenase activation protein, $\varepsilon$ polypeptide & 3762.1 & 62.2 & 6.5 & 90.51 \\
\hline 1437143_a_at & Thioredoxin domain containing 1 & 7150.4 & 41.7 & 6.5 & 90.51 \\
\hline 1455897_x_at & High mobility group nucleosomal binding domain 1 & 9034.5 & 77.7 & 6.5 & 90.51 \\
\hline 1449040_a_at & Selenophosphate synthetase 2 & 10394.9 & 103.9 & 6.4 & 84.45 \\
\hline 1434099_at & 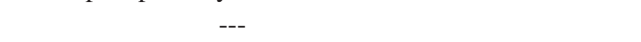 & 1091.2 & 19.6 & 6.3 & 78.79 \\
\hline 1456196_x_at & --- & 3454.6 & 47.8 & 6.3 & 78.79 \\
\hline 1420037_at & --- & 6773.1 & 85.8 & 6.3 & 78.79 \\
\hline 1449059_a_at & 3-oxoacid CoA transferase 1 & 8173.9 & 77.6 & 6.3 & 78.79 \\
\hline 1434499_a_at & Lactate dehydrogenase 2 , B chain & 9177.8 & 58.0 & 6.3 & 78.79 \\
\hline 1424827_a_at & Casein kinase $1, \alpha 1$ & 4755.4 & 39.8 & 6.2 & 73.52 \\
\hline 1434892_x_at & Retinoblastoma binding protein 4 & 7714.7 & 59.6 & 6.2 & 73.52 \\
\hline $1423890 \_x \_a t$ & ATPase, $\mathrm{Na}^{+} / \mathrm{K}^{+}$transporting, $\beta 1$ polypeptide & 76228.2 & 1190.9 & 6.2 & 73.52 \\
\hline 1430542_a_at & $\begin{array}{l}\text { Solute carrier family } 25 \text { (mitochondrial carrier, adenine } \\
\text { nucleotide translocator), member } 5 \\
\text { phosphoribosylaminoimidazole carboxylase, } \\
\text { phosphoribosylaminoribosylaminoimidazole, }\end{array}$ & 3309.2 & 41.8 & 6.2 & 73.52 \\
\hline 1436298_x_at & Succinocarboxamide synthetase & 2049.5 & 23.6 & 6.1 & 68.59 \\
\hline 143544_a_at & $\begin{array}{l}\text { Choline phosphotransferase } 1 \\
\text { ATP synthase, } \mathrm{H}^{+} \text {transporting, mitochondrial FO }\end{array}$ & 7782.3 & 153.8 & 6.1 & 68.59 \\
\hline 1416143_at & Complex, subunit F & 7867.0 & 116.2 & 6.1 & 68.59 \\
\hline 1436900_x_at & Leptin receptor overlapping transcript & 1133.7 & 19.8 & 6.0 & 64.00 \\
\hline 1427262_at & --- & 1768.5 & 46,3 & 6.0 & 64.00 \\
\hline 1456226_x_at & Discoidin domain receptor family, member 1 & 5273.1 & 57.7 & 6.0 & 64.00 \\
\hline 1436691_x_at & Peroxiredoxin 1 & 39422.3 & 367.1 & 6.0 & 64.00 \\
\hline 1439184_s_at & Thioredoxin-like 5 & 1615.9 & 24.4 & 6.0 & 64.00 \\
\hline 1435791_x_at & Ribosomal protein L17 & 2858.6 & 45.3 & 6.0 & 64.00 \\
\hline 1434056_a_at & Gene model 137, (NCBI) & 2872.6 & 52.0 & 5.9 & 59.71 \\
\hline 1456341_a_at & Basic transcription element binding protein 1 & 5894.2 & 99.7 & 5.9 & 59.71 \\
\hline 1439411_a_at & $\begin{array}{l}\text { Exportin } 7 \\
\text { Tyrosine 3-monooxygenase/tryptophan 5- }\end{array}$ & 4260.4 & 40.7 & 5.9 & 59.71 \\
\hline 1455815_a_at & Monooxygenase activation protein, $B$ polypeptide & 14398.9 & 205.9 & 5.9 & 59.71 \\
\hline 1425140_at & Lactamase, $B 2$ & 9634.1 & 55.9 & 5.9 & 59.71 \\
\hline 1433514_at & $\begin{array}{l}\text { Ethanolamine kinase } 1 \\
\text { Tyrosine 3-monooxygenase/tryptophan 5- }\end{array}$ & 2752.3 & 42.6 & 5.8 & 55.72 \\
\hline 1436783_x_at & Monooxygenase activation protein, $B$ polypeptide & 4090.5 & 94.2 & 5.8 & 55.72 \\
\hline 1416316 at & -- & 7482.6 & 104.7 & 5.8 & 55.72 \\
\hline 1420618_at & $\begin{array}{l}\text { Cytoplasmic polyadenylation element binding protein } 4 \\
\text { SWI/SNF related, matrix associated, actin dependent }\end{array}$ & 6068.4 & 55.3 & 5.8 & 55.72 \\
\hline 1430526_a_at & Regulator of chromatin, subfamily a, member 2 & 1456,4 & 21.8 & 5.8 & 55.72 \\
\hline 1426326_at & Zinc finger protein 91 & 2156.3 & 39.6 & 5.7 & 51.98 \\
\hline 1438625_s_at & Necdin /// PCTAIRE-motif protein kinase 1 & 2578.6 & 66.5 & 5,7 & 51.98 \\
\hline 1420827_a_at & -- & 2694.3 & 44.8 & 5.7 & 51.98 \\
\hline 1433704_s_at & Translocation protein 1 & 4317.0 & 112.1 & 5.7 & 51.98 \\
\hline 1418503 at & Heat shock protein, A & 2361.8 & 22.6 & 5.7 & 51.98 \\
\hline 1435164_s_at & Ubiquitin-activating enzyme E1C & 1787.0 & 14.3 & 5.7 & 51.98 \\
\hline 1416166_a_at & Peroxiredoxin 4 & 557.7 & 11.3 & 5.7 & 51.98 \\
\hline
\end{tabular}

${ }^{a}$ Average difference indicates the level of expression of the gene. ${ }^{b}$ Fold changes in average difference values were calculated using an Affymetrix software algorithm (GCOS ver 1.0). 


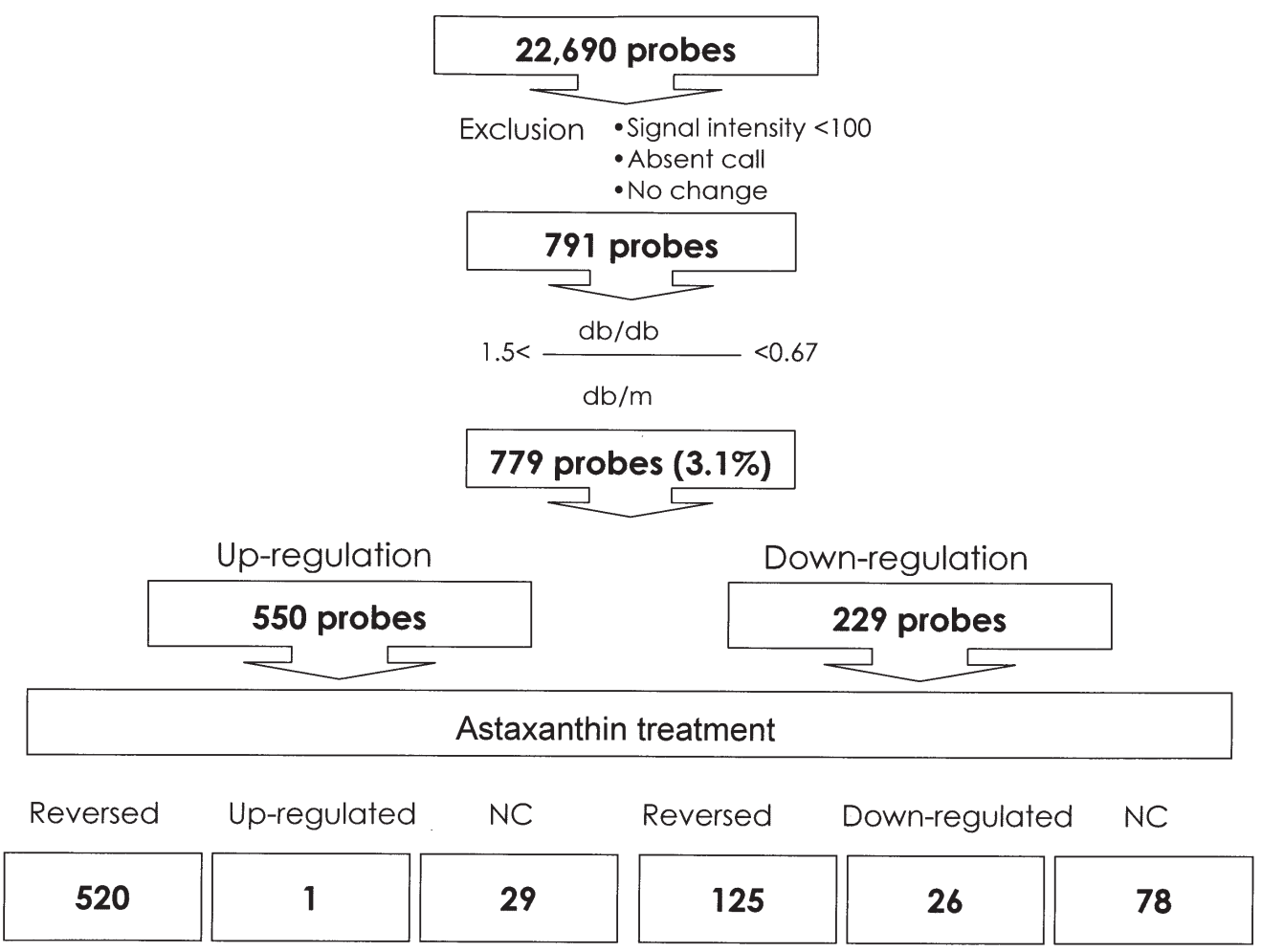

Figure 2. Up- and down-regulated probes in diabetic $\mathrm{db} / \mathrm{db}$ mice in comparison with $\mathrm{db} / \mathrm{m}$ mice, and the effect of astaxanthin on the expression of these probes.

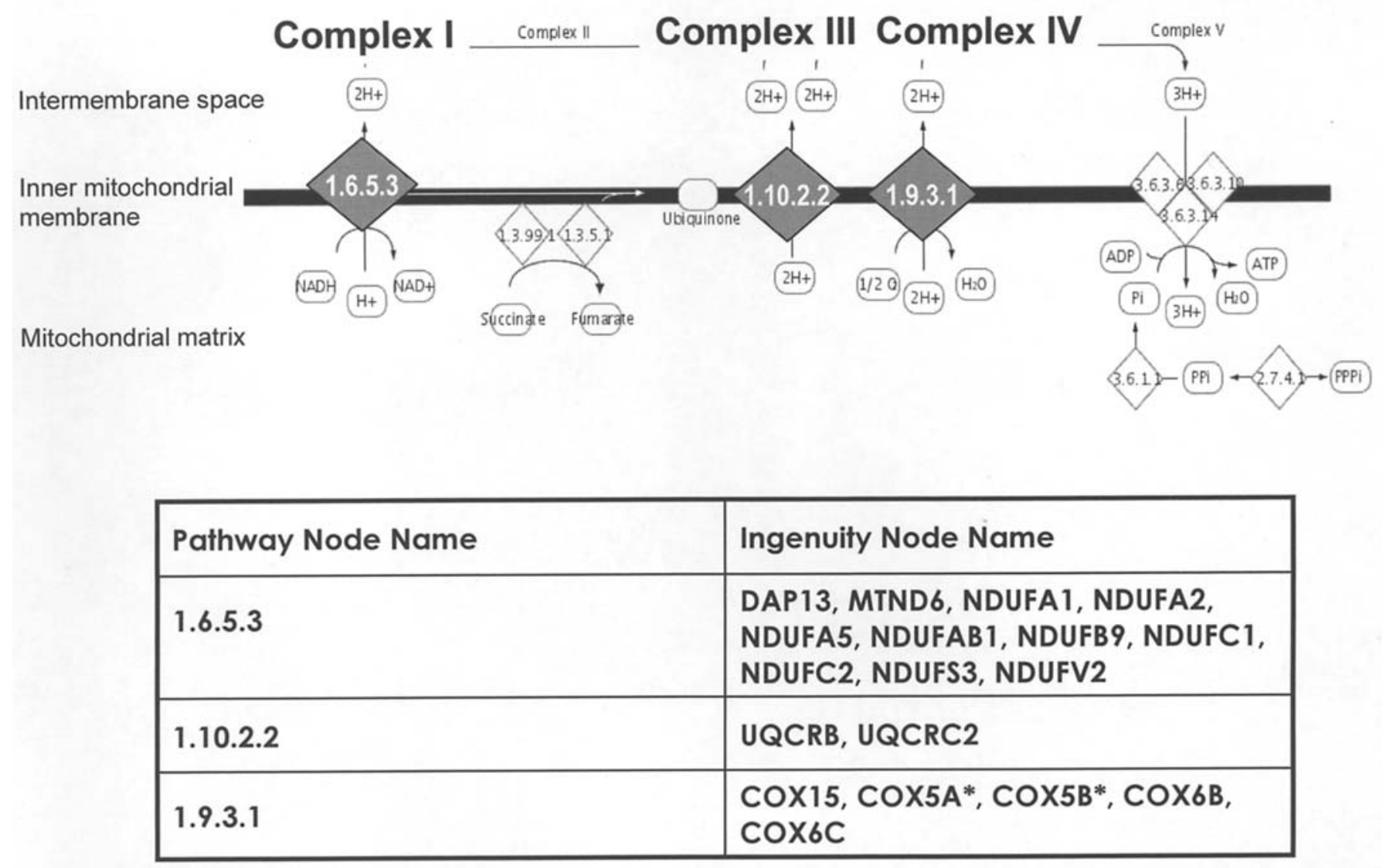

Figure 3. The oxidative phosphorylation pathway includes 20 sets of probes for genes located at the inner mitochondrial membrane. Descriptions of each probe are provided in Table IV. 
Table II. Down-regulated genes in $\mathrm{db} / \mathrm{db}$ mice.

\begin{tabular}{|c|c|c|c|c|c|}
\hline \multirow[t]{2}{*}{ Probe set ID } & \multirow[t]{2}{*}{ Descriptions } & \multicolumn{2}{|c|}{ Average difference ${ }^{\mathrm{a}}$} & \multirow[t]{2}{*}{ Log ratio } & \multirow[t]{2}{*}{ Fold change ${ }^{b}$} \\
\hline & & $\mathrm{db} / \mathrm{db}$ & $\mathrm{db} / \mathrm{m}$ & & \\
\hline 1452498_at & G patch domain containing 2 & 11.7 & 407.6 & -5.5 & 0.02 \\
\hline 1421866_at & Nuclear receptor subfamily 3 , group $C$, member 1 & 18.7 & 1014.6 & -5.4 & 0.02 \\
\hline 1421565_at & Roundabout homolog 3 (Drosophila) & 51.9 & 895.8 & -5.0 & 0.03 \\
\hline 1420392_at & RIKEN cDNA4930522D07gene & 73.2 & 1150.5 & -4.9 & 0.03 \\
\hline 1421380_at & Insulin receptor & 21.2 & 849.6 & -4.8 & 0.04 \\
\hline 1427646_a_at & Rho/rac guanine nucleotide exchange factor (GEF) 2 & 87.6 & 1978.6 & -4.5 & 0.04 \\
\hline 1450193_at & Hyperpolarization-activated, cyclic nucleotide-gated $\mathrm{K}^{+} 1$ & 75.8 & 1068.3 & -4.5 & 0.04 \\
\hline 1420229_at & --- & 26.1 & 1305.2 & -4.4 & 0.05 \\
\hline 1452129_at & Parathyroid hormone receptor 2 & 38.3 & 750.7 & -4.3 & 0.05 \\
\hline 1439995_at & Expressed sequence C 80638 & 30.4 & 1024.0 & -4.2 & 0.05 \\
\hline 1451949_at & --- & 88.6 & 1114.1 & -3.9 & 0.07 \\
\hline 1426042_at & FYVE, RhoGEF and PH domain containing 4 & 330.2 & 959.0 & -3.9 & 0.07 \\
\hline 1425645_s_at & Cytochrome P450, family 2 , subfamily b, polypeptide $10 / 20$ & 86.6 & 1301.8 & -3.9 & 0.07 \\
\hline 1434079_s_at & $\begin{array}{l}\text { Minichromosome maintenance deficient } 2 \text { mitotin (S. cerevisie) } \\
\text { KH domain containing, RNA binding, signal transduction }\end{array}$ & 80.3 & 996.7 & -3.8 & 0.07 \\
\hline 1422117_s_at & Associated 2 & 137.9 & 1484.6 & -3.8 & 0.07 \\
\hline 1419306_at & RIKEN cDNA 4921513E08 gene & 65.3 & 1141.5 & -3.7 & 0.08 \\
\hline 1426870_at & F-box only protein 33 & 86.6 & 1660.0 & -3.7 & 0.08 \\
\hline 1422926_at & Melanocortin 2 receptor & 85.0 & 1551.0 & -3.7 & 0.08 \\
\hline 1449736_at & Phosphatidylinositol-4-phosphate 5-kinase, type II, $\alpha$ & 36.3 & 791.5 & -3.6 & 0.08 \\
\hline 1422707_at & Phosphoinositide-3-kinase, catalytic, $\gamma$ polypeptide & 79.8 & 953.9 & -3.5 & 0.09 \\
\hline 1418947_at & NIMA (never in mitosis gene a)-related expressed kinase 3 & 62.4 & 1131.7 & -3.5 & 0.09 \\
\hline 1442778_at & Expressed sequence AA511254 & 131.3 & 1254.4 & -3.5 & 0.09 \\
\hline 1416746_at & $\mathrm{H} 2 \mathrm{~A}$ histone family, member $\mathrm{X}$ & 208.3 & 1766.2 & -3.5 & 0.09 \\
\hline 1422390_at & Vomeronasal 1 receptor, C5 & 143.8 & 1163.1 & -3.4 & 0.09 \\
\hline 1426333_a_at & Inhibitor of $\kappa \mathrm{B}$ kinase $\beta$ & 102.3 & 1011,0 & -3.4 & 0.09 \\
\hline 1419483_at & Complement component 3 a receptor 1 & 47.0 & 752.5 & -3.3 & 0.10 \\
\hline 1421338_at & E74-like factor 4 (ets domain transcription factor) & 207.4 & 2074.2 & -3.3 & 0.10 \\
\hline 1427889_at & spectrin $\alpha 2$ & 201.0 & 1100.0 & -3.3 & 0.10 \\
\hline 1417161_at & DNA segment, Chr 19, ERATO Doi 144, expressed & 138.3 & 1578.0 & -3.2 & 0.11 \\
\hline 1434195_at & Protease, serine, 35 & 162.5 & 930.1 & -3.1 & 0.12 \\
\hline 1421486_at & Early growth response 3 & 335.1 & 5852.2 & -3.1 & 0.12 \\
\hline 1415756_a_at & SNAP-associated protein & 128.0 & 874.1 & -3.1 & 0.12 \\
\hline 1456521_at & --- & 128.6 & 1142.5 & -3.0 & 0.13 \\
\hline 1439453_x_at & RIKEN cDNA 1500026D 16 gene & 30.3 & 692.0 & -2.9 & 0.13 \\
\hline 1438912_at & Hepatoma-derived growth factor, related protein 2 & 91.1 & 1898.0 & -2.8 & 0.14 \\
\hline 1438825_at & Calmodulin 3 & 165.6 & 3263.2 & -2.8 & 0.14 \\
\hline 1416888_at & $\begin{array}{l}\text { Fas (TNFRSF6)-associated via death domain } \\
\text { TATA box binding protein (Tbp)-associated factor, RNA }\end{array}$ & 418.1 & 1534.1 & -2.8 & 0.14 \\
\hline 1431345_a_at & Polymerase I, B & 112.8 & 1110.3 & -2.7 & 0.15 \\
\hline 1449563_at & Contactin 1 & 115.8 & 1156.2 & -2.7 & 0.15 \\
\hline 1426873_s_at & $\begin{array}{l}\text { Junction plakoglobin } \\
\text { double cortin and calcium/calmodulin-dependent protein }\end{array}$ & 481.1 & 4061.8 & -2.7 & 0.15 \\
\hline 1450863_a_at & Kinase-like 1 & 309.9 & 1276.1 & -2.7 & 0.15 \\
\hline 1419402_at & Meiosis-specific nuclear structural protein 1 & 106.8 & 983.7 & -2.7 & 0.15 \\
\hline 1448000_at & Cell division cycle associated 3 & 371.3 & 706.2 & -2.6 & 0.16 \\
\hline 1422202_at & Thyroid hormone receptor $\beta$ & 221.5 & 788.0 & -2.6 & 0.16 \\
\hline 1424040_at & cDNA sequence BC019977 & 428.2 & 2446.4 & -2.6 & 0.16 \\
\hline 1456697_x_at & Cyclin D binding myb-like transcription factor 1 & 390.7 & 1712.3 & -2.5 & 0.18 \\
\hline 1450319_at & $\gamma$-aminobutyric acid (GABA-A) receptor, subunit $\beta 2$ & 287.8 & 3465.3 & -2.5 & 0.18 \\
\hline 1418132_a_at & DNA segment, Chr 7, Wayne State University 128, expressed & 690.7 & 3617.5 & -2.5 & 0.18 \\
\hline 1425276_at & Fibrosin 1 & 128.6 & 814.1 & -2.4 & 0.19 \\
\hline 1427552_a_at & Glutathione transferase $\zeta 1$ (maleylacetoacetate isomeras & 430.8 & 1036.7 & -2.4 & 0.19 \\
\hline
\end{tabular}

${ }^{a}$ Average difference indicates the level of expression of the gene. ${ }^{b}$ Fold changes in average difference values were calculated using an Affymetrix software algorithm (GCOS ver. 1.) 
Table III. Ingenuity canonical pathway analysis for up-regulated genes in diabetic $\mathrm{db} / \mathrm{db}$ mice.

\begin{tabular}{|c|c|c|}
\hline Canonical pathway & Significance & Genes \\
\hline Oxidative phosphorylation & $393 \times 10^{-8}$ & $\begin{array}{l}\text { COX15, COX5A }{ }^{\mathrm{a}} \text {, COX5Ba , COX6B, COX6C, DAP13, } \\
\text { MTND6, NDUFA1, NDUFA2, NDUFA5, NDUFAB1, NDUFB9, } \\
\text { NDUFC1, NDUFC2, NDUFS3, NDUFV2, UQCRB, UQCRC2 }\end{array}$ \\
\hline Citrate cycle & $1.64 \times 10^{-6}$ & ACLY, ATP5G3, CS, FH, IDH1 ${ }^{\mathrm{a}}$, IDH3B, MDH1 ${ }^{\mathrm{a}}$, MDH2, SUCLA2 \\
\hline Ubiquinone biosynthesis & $4.07 \times 10^{-6}$ & $\begin{array}{l}\text { DAP13, MTND6, NDUFA1, NDUFA2, NDUFA5, NDUFAB1, } \\
\text { NDUFB9, NDUFC1, NDUFC2, NDUFS3, NDUFV2 }\end{array}$ \\
\hline Pyruvate metabolism & $2.33 \times 10^{-4}$ & $\begin{array}{l}\text { ACAA1, ACAS2L, ACAT1, ADH5, AKR1A1 }{ }^{\mathrm{a}} \text {, ALDH9A1, GL01, } \\
\text { HADHB, LDHB, MDH1 }{ }^{\mathrm{a}}, \mathrm{MDH} 2\end{array}$ \\
\hline Fatty acid biosynthesis (path 2) & $6.99 \times 10^{-4}$ & ACAA1, ACAT1, EHHADH, HADHB, HADHSC ${ }^{a}$ \\
\hline Synthesis and degradation of ketone bodies & $7.57 \times 10^{-3}$ & ACAT1, HMGCS1 $1^{\text {a }}$ OXCT ${ }^{\text {a }}$ \\
\hline
\end{tabular}

${ }^{a}$ Duplicates. Gene/Protein IDs with multiple identifiers from the input list mapped to a single gene in the Global Molecular Network.

biosynthesis, and the synthesis/degradation of ketone bodies. The results regarding networks associated with the oxidative phosphorylation pathway were found to be highly significant, since a greater number of identified genes were present in this pathway than would be expected by chance. This pathway includes 20 probe sets for genes located at the inner mitochondrial membrane, and these genes are members of the electron transport system complexes I, III, and IV (Fig. 3). The abnormal up-regulation of these genes may be associated with the increased production of reactive oxygen species (ROS) from the mitochondrial membrane, which has also been demonstrated in previous studies. Recently, Nishikawa et al (11) showed that the hyperglycemia-induced production of ROS is abrogated by inhibitors of mitochondrial metabolism or by the overexpression of uncoupling protein-1 (UCP-1) or manganese superoxide dismutase (MnSOD). In addition, normalization of mitochondrial ROS production by each of these agents can prevent glucose-induced activation of protein kinase $\mathrm{C}$, the formation of advanced glycation end products, the accumulation of sorbitol, and the activation of nuclear factor $\mathrm{kb}(\mathrm{NF}-\mathrm{kb})$ in bovine vascular endothelial cells, as well as in cultured human mesangial cells $(11,12)$, all of which are known to be involved in the development of diabetic complications. The present study showed that the expression of up-regulated mitochondrial genes was decreased by treatment with astaxanthin (Table IV). These data may suggest that astaxanthin can reverse the abnormal function of glomerular cell mitochondria in diabetic $\mathrm{db} / \mathrm{db}$ mice.

Next, in order to focus on diabetic nephropathy, the number of genes was narrowed down to 247 probe sets, which were selected using software of NetAffyx ${ }^{\mathrm{TM}}$ analysis center (http://www.affymetrix.com/analysis/index.affx, July 1, 2005) and the following keywords; oxidative stress, transforming growth factor (TGF), and collagen. Among 90 probes related to oxidative stress, 21 were up-regulated in the diabetic $\mathrm{db} / \mathrm{db}$ mice, as compared to the $\mathrm{db} / \mathrm{m}$ mice. As shown in Table V, 3 probes of tyrosine 3-monooxygenase were upregulated at least 8.0 -fold in the diabetic mice in comparison with the $\mathrm{db} / \mathrm{m}$ mice; however, there were no significant differences between the $\mathrm{db} / \mathrm{db}$ mice and the astaxanthintreated $\mathrm{db} / \mathrm{db}$ mice. The peroxiredoxin 1 gene probe (1436691_x_at) was a highly up-regulated gene in diabetic mice and was significantly reduced by a ratio of 0.14 by treatment with astaxanthin. In the mouse expression array 430A (Affymetrix), four probe sets were included for the peroxiredoxin gene: 1436691_x_at, 1433866_x_at, 1434731 _x_at, and 1437014_x_at. The expression of all four probes was up-regulated at least 8.0 -fold in the diabetic mice, and was down-regulated by treatment with astaxanthin (Table V). Peroxiredoxin 1 has been shown to play an important role in the defense against oxidative stress (13), and thus the enhanced expression of peroxiredoxin 1 indicates the presence of such stress. Similar to peroxiredoxin 1 expression, the mRNA expression of catalase (1416430_at, 1416429 _a_at), superoxide dismutase 1 (1451124_at), and glutathione peroxidase 3 (1449106_at) was also increased in diabetic mice, and these increases were significantly inhibited by treatment with astaxanthin. Our previous study showed that astaxanthin accumulated in the kidneys of mice after 3 weeks of the administration of a diet containing $0.02 \%$ astaxanthin (8). Therefore, the inhibition of the expression of these oxidative stress-responsive genes by an astaxanthincontaining diet, demonstrated in the present study, may indicate that astaxanthin absorbed from the intestine can act as an antioxidant in the glomerular lesion in vivo. The present data are also consistent with those of the our previous study, in which urinary and kidney 8-hydroxydeoxyguanosine levels, an index of oxidative DNA damage, exhibited marked reduction by treatment with astaxanthin, in spite of high blood glucose conditions.

It has been demonstrated that the activation of protein kinase $\mathrm{C}$ (PKC) and the stimulation of the fibrogenic TGF- $\beta$ system by diabetogenic factors such as hyperglycemia and increased protein glycation are pathogenetically linked to the process of diabetic nephropathy (14-16). Diabetic nephropathy is also associated with renal overproduction of the extracellular matrix proteins fibronectin and type IV collagen, as well as with the increased expression of the mRNA encoding these proteins $(17,18)$. The importance of TGF- $\beta$ signaling in the 
Table IV. Up-regulation of mitochondrial oxidative phosphorylation-related genes and their inhibition by astaxanthin.

\begin{tabular}{|c|c|c|c|c|c|c|c|c|c|c|}
\hline \multirow[t]{2}{*}{ Probe set ID } & \multirow[t]{2}{*}{ Gene } & \multirow[t]{2}{*}{ Descriptions } & \multirow[t]{2}{*}{ Complex $^{\mathrm{a}}$} & \multicolumn{3}{|c|}{ Average differerence ${ }^{\mathrm{a}}$} & \multicolumn{2}{|c|}{ Diabetic/normal } & \multicolumn{2}{|c|}{ Astaxanthin/diabetic } \\
\hline & & & & $\begin{array}{c}\text { Normal } \\
\mathrm{db} / \mathrm{m})\end{array}$ & $\begin{array}{l}\text { Diabetic } \\
(\mathrm{db} / \mathrm{db})\end{array}$ & Astaxanthin & $\begin{array}{l}\text { Fold } \\
\text { change }^{b}\end{array}$ & Change $^{c}$ & $\begin{array}{l}\text { Fold } \\
\text { change }^{\mathrm{b}}\end{array}$ & Change $^{c}$ \\
\hline 1437982_x_at & $\operatorname{COX} 15$ & $\begin{array}{l}\text { COX15 homolog, cytochrome c } \\
\text { oxidase assembly protein (yeast) }\end{array}$ & I & 87.9 & 1364.1 & 568.5 & 8.57 & I & 0.35 & $\mathrm{D}$ \\
\hline 1415933_a_at & COX5A & Cytochrome c oxidase, subunit $\mathrm{Va}$ & I & 319.2 & 13526.1 & 1413.6 & 42.22 & I & 0.11 & $\mathrm{D}$ \\
\hline 1439267_x_at & COX5A & Cytochrome c oxidase, subunit Va & I & 113.1 & 3745.5 & 473.8 & 27.86 & I & 0.08 & $\mathrm{D}$ \\
\hline 1454716_x_at & COX5B & Cytochrome $\mathrm{c}$ oxidase, subunit $\mathrm{Vb}$ & I & 119.8 & 3289.9 & 131.3 & 24.25 & I & 0.04 & $\mathrm{D}$ \\
\hline 1456588_x_at & COX5B & Cytochrome $\mathrm{c}$ oxidase, subunit $\mathrm{Vb}$ & I & 455.9 & 12085.5 & 971.6 & 24.25 & I & 0.11 & $\mathrm{D}$ \\
\hline 1436757_a_at & COX6B & $\begin{array}{l}\text { Cytochrome } \mathrm{c} \text { oxidase, subunit Vlb } \\
\text { polypeptide } 1\end{array}$ & I & 507.4 & 27966.1 & 3613.4 & 24.25 & I & 0.13 & $\mathrm{D}$ \\
\hline 1434491_a_at & COX6C & --- & I & 1544.9 & 11653.9 & 2087.8 & 18.38 & I & 0.22 & $\mathrm{D}$ \\
\hline 1455997_a_at & UQCRB & $\begin{array}{l}\text { Ubiquinol-cytochrome } \mathrm{c} \text { reductase } \\
\text { binding protein }\end{array}$ & III & 3691.3 & 67817.7 & 8314.1 & 22.63 & I & 0.13 & $\mathrm{D}$ \\
\hline 1435757_a_at & UQCRC2 & $\begin{array}{l}\text { Ubiquinol cytochrome c reductase } \\
\text { core protein } 2\end{array}$ & III & 139.7 & 4108.4 & 603.3 & 34.30 & I & 0.13 & $\mathrm{D}$ \\
\hline 1455806_x_at & DAP13 & RIKEN cDNA 2410011 G03 gene & IV & 93.0 & 1738.4 & 125.6 & 13.00 & I & 0.08 & MD \\
\hline 1426088_at & MTND6 & --- & IV & 3578.9 & 87672.0 & 12739.6 & 21.11 & I & 0.18 & $\mathrm{D}$ \\
\hline 1422241_a_at & NDUFA1 & $\begin{array}{l}\text { NADH dehydrogenase (ubiquinone) } 1 \text {, } \\
\alpha \text { subcomplex, } 1\end{array}$ & IV & 1324.9 & 15002.2 & 1458.0 & 9.19 & I & 0.11 & $\mathrm{D}$ \\
\hline 1417368_s_at & NDUFA2 & $\begin{array}{l}\text { NADH dehydrogenase (ubiquinone) } 1 \text {, } \\
\alpha \text { subcomplex, } 2\end{array}$ & 1, IV & 744.8 & 2544.3 & 178.8 & 4.29 & I & 0.04 & MD \\
\hline 1417285_a_at & NDUFA5 & $\begin{array}{l}\text { NADH dehydrogenase (ubiquinone) } 1 \text {, } \\
\alpha \text { subcomplex, } 5\end{array}$ & 1, IV & 44.7 & 6785.8 & 1440.3 & 36.76 & I & 0.16 & D \\
\hline 1447919_x_at & NDUFAB1 & $\begin{array}{l}\text { NADH dehydrogenase (ubiquinone) } 1 \text {, } \\
\alpha / ß \text { subcomplex, } 1\end{array}$ & 1, IV & 380.9 & 3425.9 & 782.6 & 12.13 & I & 0.29 & $\mathrm{NC}$ \\
\hline 1436803_a_at & NDUFB9 & $\begin{array}{l}\text { NADH dehydrogenase (ubiquinone) } 1 \text {, } \\
\text { ß subcomplex, } 9\end{array}$ & IV & 226.8 & 6186.5 & 1556.8 & 13.93 & I & 0.33 & $\mathrm{NC}$ \\
\hline 1448284_a_at & NDUFC1 & $\begin{array}{l}\text { NADH dehydrogenase (ubiquinone) } 1 \text {, } \\
\text { subcomplex unknown, } 1\end{array}$ & 1, IV & 214.0 & 3344.7 & 848.2 & 14.93 & I & 0.27 & $\mathrm{NC}$ \\
\hline 1455036_s_at & NDUFC2 & $\begin{array}{l}\text { NADH dehydrogenase (ubiquinone) } 1 \text {, } \\
\text { subcomplex unknown, } 2\end{array}$ & 1, IV & 232.8 & 24253.0 & 2846.3 & 36.76 & I & 0.14 & $\mathrm{D}$ \\
\hline 1423737_at & NDUFS3 & $\begin{array}{l}\text { NADH dehydrogenase (ubiquinone) } \\
\text { Fe-S protein } 3\end{array}$ & IV & 94.6 & 1022.0 & 277.7 & 13.93 & 1 & 0.12 & $\mathrm{NC}$ \\
\hline 1452692_a_at & NDUFV2 & $\begin{array}{l}\text { NADH dehydrogenase (ubiquinone) } \\
\text { flavoprotein } 2\end{array}$ & IV & 995.3 & 3681.2 & 403.6 & 3.48 & 1 & 0.12 & $\mathrm{D}$ \\
\hline
\end{tabular}

${ }^{a}$ Average difference indicates the level of expression of the gene. ${ }^{b}$ Fold changes in average difference values were calculated using an Affymetrix software algorithm (GCOS ver. 1.0). ${ }^{\mathrm{c}} \mathrm{I}$, increase; D, decrease; and NC, no change in the average difference.

pathophysiology of diabetic nephropathy is, in part, confirmed by the results of the present study. Of the 157 probes for genes related to TGF- $\beta$ and collagen signaling, 24 were upregulated in diabetic $\mathrm{db} / \mathrm{db}$ mice, as compared to $\mathrm{db} / \mathrm{m}$ mice (Table V). Of the 24 up-regulated probes, the expression of only 5 (transglutaminase 2 , guanine nucleotide binding protein, proteasome subunit $B 3$, ubiquitin $B$, and secreted phosphoprotein) was significantly decreased by the treatment with astaxanthin, as shown in Table V.

We observed increased expression of two probes of transglutaminase 2 (1433428_x_at, 1437277_x_at) in the $\mathrm{db} / \mathrm{db}$ mice. It has been reported that tissue transglutaminase enzyme is implicated in protein crosslinking by the formation of increased $\varepsilon$-( $\gamma$-glutamyl) lysine bonds between extracellular matrix components in the diabetic kidneys of both $\mathrm{db} / \mathrm{db}$ mice and human patients with diabetes (19). The present study revealed that this increased expression was markedly reversed by treatment with astaxanthin. These data indicate the possible pathogenic role of transglutaminase 2 in the development of diabetic nephropathy. Furthermore, secreted phosphoprotein 1 is known to be a homolog of human osteopontin. Recent studies have demonstrated that osteopontin plays a role in regulating the accelerated mesangial cell growth and collagen synthesis found in a hyperglycemic environment (20), and it has also been shown that plasma osteopontin is elevated along with the progression of diabetic nephropathy (21). In the present study, a probe of secreted phosphoprotein 1 (1449254_at) was up-regulated at a ratio of 4.92 in diabetic mice, and this effect was significantly inhibited by treatment with astaxanthin at a ratio of 0.13 . These findings suggest that secreted phosphoprotein 1 may be a good bio-marker for evaluating the efficacy of dietary food 
Table V. The effects of astaxanthin treatment on oxidative stress-, cytokine-, TGF-, and collagen-related gene expression.

\begin{tabular}{|c|c|c|c|c|c|c|c|c|}
\hline \multirow[t]{2}{*}{ Probe set ID } & \multirow[t]{2}{*}{ Descriptions } & \multicolumn{3}{|c|}{ Average differerence ${ }^{a}$} & \multicolumn{2}{|c|}{ Diabetic/normal } & \multicolumn{2}{|c|}{ Astaxanthin/diabet } \\
\hline & & $\begin{array}{c}\text { Normal } \\
\mathrm{db} / \mathrm{m})\end{array}$ & $\begin{array}{l}\text { Diabetic } \\
(\mathrm{db} / \mathrm{db})\end{array}$ & Astaxanthin & $\begin{array}{c}\text { Fold } \\
\text { change }^{b}\end{array}$ & Change $^{c}$ & $\begin{array}{c}\text { Fold } \\
\text { change }^{\mathrm{b}}\end{array}$ & Change \\
\hline \multicolumn{9}{|l|}{ Oxidative stress } \\
\hline 1426385_x_at & $\begin{array}{l}\text { Tyrosine 3-monooxygenase/tryptophan } \\
5 \text {-monooxygenaseactivation protein, } \varepsilon \text { polypeptide }\end{array}$ & 62.2 & 3762.1 & 1053.6 & 90.51 & I & 0.25 & $\mathrm{NC}$ \\
\hline 1436691_x_at & Peroxiredoxin 1 & 367.1 & 39422.3 & 5075.8 & 64.00 & I & 0.14 & $\mathrm{D}$ \\
\hline 1425993_a_at & Heat shock protein 105 & 34.5 & 1804.2 & 174.5 & 34.30 & I & 0.09 & $\mathrm{NC}$ \\
\hline 1427442_a_at & Amyloid B (A4) precursor protein & 340.3 & 20915.3 & 4786.4 & 34.30 & I & 0.25 & $\mathrm{D}$ \\
\hline 1439443_x_at & Transketolase & 190.2 & 7265.6 & 1082.8 & 32.00 & I & 0.14 & D \\
\hline 1416430_at & Catalase & 53.5 & 1011.5 & 360.9 & 25.99 & I & 0.33 & $\mathrm{NC}$ \\
\hline 1419821_s_at & Isocitrate dehydrogenase $1\left(\mathrm{NADP}^{+}\right)$, soluble & 118.3 & 2713.1 & 1141.9 & 21.11 & I & 0.33 & $\mathrm{NC}$ \\
\hline 1416429_a_at & Catalase & 666,3 & 12753.2 & 3273.1 & 18.38 & I & 0.13 & $\mathrm{D}$ \\
\hline 1433866_x_at & Peroxiredoxin 1 & 899.7 & 8801.4 & 1255.8 & 18.38 & I & 0.18 & $\mathrm{D}$ \\
\hline 1418180_at & Trans-acting transcription factor 1 & 73.0 & 1358.2 & 527.7 & 18.38 & Ml & 0.38 & $\mathrm{NC}$ \\
\hline 1451124_at & Superoxide dismutase 1 , soluble & 169.9 & 5222.6 & 1160.1 & 17.15 & I & 0.23 & $\mathrm{D}$ \\
\hline 1418127_a_at & Programmed cell death 8 & 130.7 & 1978.9 & 1072.6 & 16.00 & I & 0.27 & $\mathrm{D}$ \\
\hline 1434731_x_at & Peroxiredoxin 1 & 1701.0 & 19840.5 & 4196.7 & 12.13 & I & 0.11 & $\mathrm{D}$ \\
\hline 1448808_a_at & Expressed in non-metastatic cells 2, protein & 1462.9 & 9564.2 & 1215.9 & 11.31 & I & 0.13 & $\mathrm{D}$ \\
\hline 1422433_s_at & Isocitrate dehydrogenase $1\left(\mathrm{NADP}^{+}\right)$, soluble & 520.3 & 7709.1 & 271.7 & 10.56 & I & 0.03 & $\mathrm{D}$ \\
\hline 1426384_a_at & $\begin{array}{l}\text { Tyrosine 3-monooxygenase/tryptophan } \\
5 \text {-monooxygenase activation protein, } \varepsilon \text { polypeptide }\end{array}$ & 63.7 & 1486.3 & 592.5 & 9.85 & I & 0.25 & NC \\
\hline 1438839_a_at & $\begin{array}{l}\text { Tyrosine } 3 \text {-monooxygenase/tryptophan } \\
5 \text {-monooxygenase activation protein, } \varepsilon \text { polypeptide }\end{array}$ & 495.2 & 3111.5 & 899.5 & 8.00 & I & 0.31 & $\mathrm{NC}$ \\
\hline 1437014_x_at & Peroxiredoxin 1 & 507.4 & 2643.9 & 600.8 & 8.00 & Ml & 0.27 & $\mathrm{D}$ \\
\hline 1449254_at & Secreted phosphoprotein 1 & 1563.0 & 5812.8 & 593.1 & 4.92 & I & 0.13 & $\mathrm{D}$ \\
\hline 1434831_a_at & Forkhead box 03a & 514.0 & 1987.5 & 116.4 & 4.29 & I & 0.05 & $\mathrm{D}$ \\
\hline 1449106_at & Glutathione peroxidase 3 & 2488.7 & 7390.7 & 1745.1 & 4.29 & Ml & 0.20 & $\mathrm{D}$ \\
\hline \multicolumn{9}{|l|}{ Cytokine } \\
\hline 1454610_at & Septin 7 & 38.9 & 2514.8 & 2360.3 & 48.50 & I & 0.76 & $\mathrm{NC}$ \\
\hline 1437457_a_at & Myotrophin & 51.1 & 3157.9 & 897.4 & 42.22 & I & 0.29 & MD \\
\hline 1451989_a_at & $\begin{array}{l}\text { Microtubule-associated protein, RP/EB family, } \\
\text { member } 2\end{array}$ & 142.1 & 5344.7 & 966.4 & 39.40 & I & 0.23 & $\mathrm{NC}$ \\
\hline 1434529_x_at & Checkpoint with forkhead and ring finger domains & 32.4 & 805.8 & 1164.5 & 32.00 & I & 1.23 & $\mathrm{NC}$ \\
\hline 1422486_a_at & MAD homolog 4 (Drosophila) & 26.4 & 816.7 & 934.6 & 27.86 & I & 1.00 & $\mathrm{NC}$ \\
\hline 1448334_a_at & Cyclin I & 92.0 & 3010.4 & 1323.8 & 24.25 & I & 0.47 & $\mathrm{NC}$ \\
\hline 1416176_at & High mobility group box 1 & 164.6 & 2739.8 & 83.7 & 22.63 & I & 0.03 & $\mathrm{D}$ \\
\hline 1437995_x_at & Septin 7 & 47.2 & 1146.4 & 783.0 & 22.63 & I & 0.76 & NC \\
\hline 1439405_x_at & RIKEN cDNA $1700051 \mathrm{C} 09$ gene & 570.9 & 8937.8 & 2467.5 & 22.63 & I & 0.27 & $\mathrm{D}$ \\
\hline 1455626_at & Homeo box A9 & 120.8 & 2330.3 & 102.5 & 22.63 & Ml & 0.04 & $\mathrm{D}$ \\
\hline 1435324_x_at & High mobility group box 1 & 59.0 & 1656.7 & 454.6 & 21.11 & I & 0.31 & $\mathrm{NC}$ \\
\hline 1425048_a_at & High mobility group box 1 & 132.9 & 2033.4 & 735.2 & 17.15 & I & 0.44 & MD \\
\hline 1438629_x_at & Granulin & 2323.6 & 26762.6 & 5119.1 & 16.00 & I & 0.19 & $\mathrm{D}$ \\
\hline 1433540_x_at & Protein phosphatase 1 , catalytic subunit, $B$ isoform & 237.0 & 4846.0 & 755.6 & 14.93 & I & 0.27 & $\mathrm{D}$ \\
\hline 1439463_x_at & Isomerase & 75.0 & 1434.8 & 589.2 & 13.00 & Ml & 0.41 & $\mathrm{NC}$ \\
\hline 1423792_a_at & Chemokine-like factor super family 6 & 46.6 & 1161.3 & 1603.3 & 11.31 & I & 1.23 & $\mathrm{NC}$ \\
\hline 1420474_at & Myotrophin & 582.9 & 6052.3 & 1817.3 & 7.46 & I & 0.41 & $\mathrm{NC}$ \\
\hline 1431765_a_at & Ribosomal protein S2 & 866.9 & 5207.0 & 1206.8 & 6.50 & I & 0.23 & $\mathrm{D}$ \\
\hline MURINE_B2_at & Adenylosuccinate lyase & 6470.5 & 45995.2 & 19116.6 & 6.50 & I & 0.35 & $\mathrm{NC}$ \\
\hline 1451114_a & Chemokine-like factor super family 6 & 287.4 & 1789.7 & 225.8 & 5.66 & I & 0.15 & $\mathrm{NC}$ \\
\hline 1417606_a_at & Calreticulin & 321.4 & 4176.6 & 1208.7 & 4.92 & I & 0.41 & $\mathrm{NC}$ \\
\hline 1449254_at & Secreted phosphoprotein 1 & 1563.0 & 5812.8 & 593.1 & 4.92 & I & 0.13 & $\mathrm{D}$ \\
\hline \multicolumn{9}{|l|}{ Collagen } \\
\hline 1456226_x_at & Discoidin domain receptor family, member 1 & 57.7 & 5273.1 & 653.1 & 64.00 & I & 0.18 & NC \\
\hline 1420811_a_at & Catenin $\beta$ & 601.6 & 15719.3 & 6513.9 & 32.00 & I & 0.38 & $\mathrm{NC}$ \\
\hline 1422486_a_at & MAD homolog 4 (Drosophila) & 26.4 & 816.7 & 934.6 & 27.86 & I & 1.00 & $\mathrm{NC}$ \\
\hline 1435820_x_at & Discoidin domain receptor family, member 1 & 57.5 & 1563.4 & 685.2 & 24.25 & I & 0.35 & NC \\
\hline 1437277_x_at & Transglutaminase $2, \mathrm{C}$ polypeptide & 717.6 & 11049.1 & 226.1 & 11.31 & I & 0.14 & D \\
\hline
\end{tabular}


Table V. Continued.

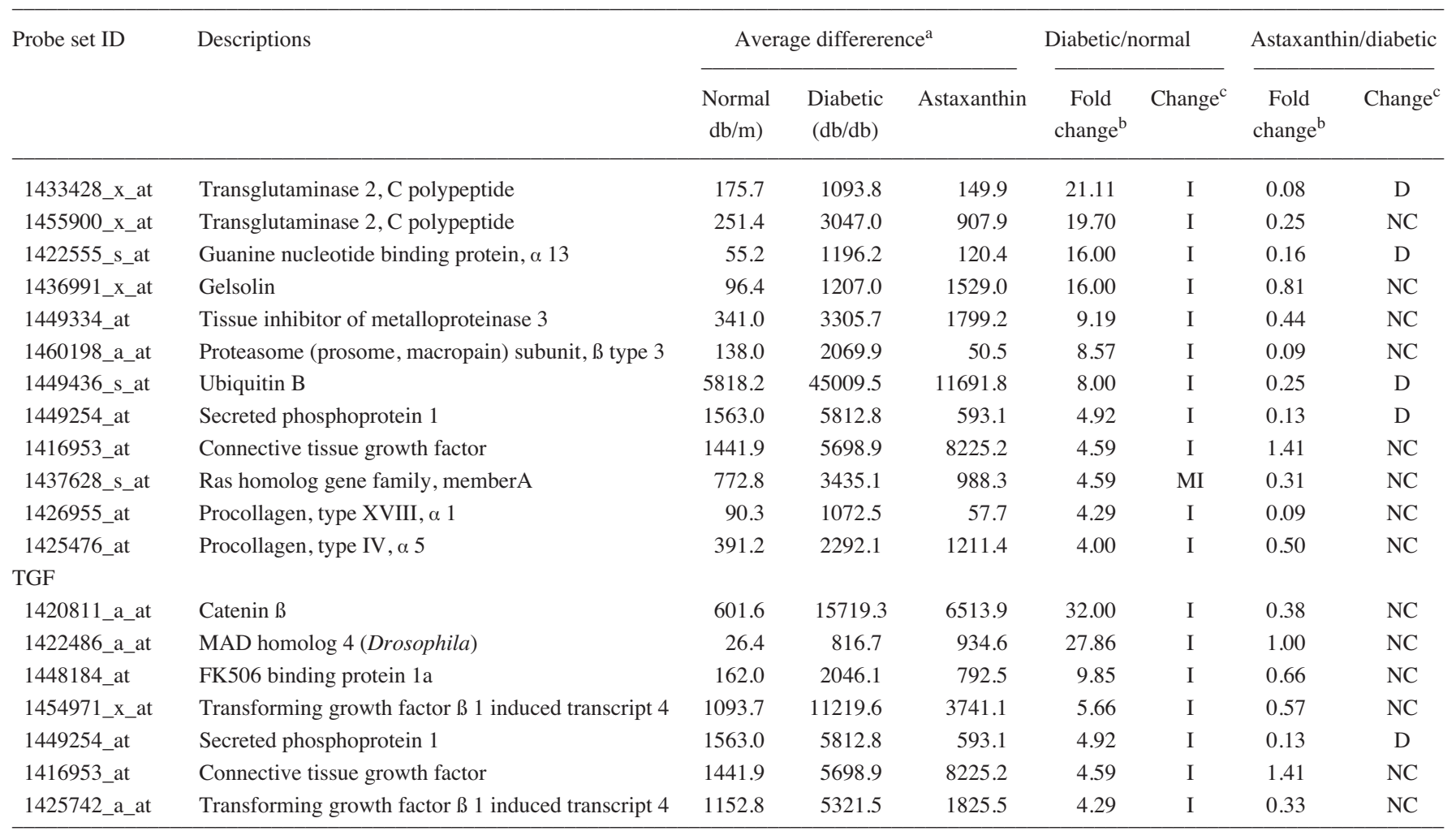

a Average difference indicates the level of expression of the gene. ${ }^{b}$ Fold changes in average difference values were calculated using an Affymetrix software algorithm (GCOS ver. 1.0). 'I, increase; MI, marginal increase; D, decrease; MD, marginal decrease; and NC, no change in the average difference.

factors against diabetic nephropathy. In addition, some genes associated with TGF- $\beta$ and collagen signaling were upregulated in the present study, such as connective tissue growth factor (CTGF), TGF- $\beta$ 1-induced transcript 4 , and type IV procollagen. Although the significant roles played by these genes in the pathogenesis of diabetic nephropathy have been demonstrated, the inhibition of their expression by astaxanthin was not found to to be statistically significant in the present study.

In conclusion, changes in the gene expression profile of glomerular cells in the early phase of diabetic nephropathy in $\mathrm{db} / \mathrm{db}$ mice were surveyed by laser capture microdissection/ GeneChip analysis. In a comparison of $\mathrm{db} / \mathrm{m}$ and $\mathrm{db} / \mathrm{db}$ mice, we found that 779 probes showed $a \geq 1.5$-fold difference with respect to the expression levels in each type of mouse. We identified the mitochondrial oxidative phosphorylation pathway as the caronical pathway that is most significantly affected by diabetic nephropathy in mice. Long-term treatment with astaxanthin significantly decreased the expression of upregulated probes, including those genes associated with oxidative phosphorylation, oxidative stress, and the TGF- $\beta$ collagen synthesis system.

\section{Acknowledgements}

This work was supported by a Grant-in-Aid for Scientific Research (15390178 TY) from the Ministry of Education, Culture, Sports, Science and Technology of Japan, and by grants from the Bio-oriented Technology Research
Advancement Institution, the Ministry of Agriculture, Forestry and Fisheries of Japan, and from Suzuken Memorial Foundation.

\section{References}

1. Kaneto H, Kajimoto Y, Miyagawa J, et al: Beneficial effects of antioxidants in diabetes: possible protection of pancreatic betacells against glucose toxicity. Diabetes 48: 2398-2406, 1999.

2. Inoguchi $\mathrm{T}$, Tsubouchi $\mathrm{H}$, Etoh $\mathrm{T}$, et al: A possible target of antioxidative therapy for diabetic vascular complicationsvascular NAD(P)H oxidase. Curr Med Chem 10: 1759-1764, 2003.

3. Koya D, Hayashi K, Kitada M, Kashiwagi A, Kikkawa R and Haneda M: Effects of antioxidants in diabetes-induced oxidative stress in the glomeruli of diabetic rats. J Am Soc Nephrol 14 Suppl 3: S250-253, 2003.

4. Maritim AC, Sanders RA and Watkins JB: Effects of alphalipoic acid on biomarkers of oxidative stress in streptozotocininduced diabetic rats. J Nutr Biochem 14: 288-294, 2003.

5. Naguib YM: Antioxidant activities of astaxanthin and related carotenoids. J Agric Food Chem 48: 1150-1154, 2000.

6. Fukuhara K, Inokami Y, Tokumura A, Terao J and Suzuki A: Rate conctants for quenching singlet oxygen and activities for inhibiting lipid peroxidation of carotenoids and alphatocopherol in liposomes. Lipids 33: 751-756, 1998.

7. Uchiyama K, Naito Y, Hasegawa G, Nakamura N, Takahashi J and Yoshikawa T: Astaxanthin protects beta-cells against glucose toxicity in diabetic db/db mice. Redox Rep 7: 290-293, 2002.

8. Naito Y, Uchiyama K, Aoi W, et al: Prevention of diabetic nephropathy by treatment with astaxanthin in diabetic $\mathrm{db} / \mathrm{db}$ mice. BioFactors 20: 49-59, 2004.

9. Connolly SB, Sadlier D, Kieran NE, Doran P and Brady HR: Transcriptome profiling and the pathogenesis of diabetic complications. J Am Soc Nephrol 14: S279-283, 2003. 
10. Hohenadel D and van der Woude FJ: Gene expression in diabetic nephropathy. Curr Diab Rep 4: 462-469, 2004.

11. Nishikawa T, Edelstein D, Du XL, et al: Normalizing mitochondrial superoxide production blocks three pathways of hyperglycaemic damage. Nature 404: 787-790, 2000.

12. Kiritoshi S, Nishikawa T, Sonoda K, et al: Reactive oxygen species from mitochondria induce cyclooxygenase-2 gene expression in human mesangial cells: potential role in diabetic nephropathy. Diabetes 52: 2570-2577, 2003.

13. Neumann CA, Krause DS, Carman CV, et al: Essential role for the peroxiredoxin Prdx1 in erythrocyte antioxidant defence and tumour suppression. Nature 424: 561-565, 2003.

14. Cohen MP, Sharma K, Guo J, Eltayeb BO and Ziyadeh FN: The renal TGF-beta system in the $\mathrm{db} / \mathrm{db}$ mouse model of diabetic nephropathy. Exp Nephrol 6: 226-233, 1998.

15. Hong SW, Isono M, Chen S, Iglesias-De La Cruz MC, Han DC and Ziyadeh FN: Increased glomerular and tubular expression of transforming growth factor-beta 1, its type II receptor, and activation of the Smad signaling pathway in the $\mathrm{db} / \mathrm{db}$ mouse. Am J Pathol 158: 1653-1663, 2001.

16. Chen S, Iglesias-de la Cruz MC, Jim B, Hong SW, Isono M and Ziyadeh FN: Reversibility of established diabetic glomerulopathy by anti-TGF-beta antibodies in $\mathrm{db} / \mathrm{db}$ mice. Biochem Biophys Res Commun 300: 16-22, 2003.
17. Zdunek M, Silbiger S, Lei J and Neugarten J: Protein kinase CK2 mediates TGF-beta1-stimulated type IV collagen gene transcription and its reversal by estradiol. Kidney Int 60: 2097-2108, 2001.

18. Cohen MP, Hud E, Shea E and Shearman CW: Normalizing glycated albumin reduces increased urinary collagen IV and prevents renal insufficiency in diabetic $\mathrm{db} / \mathrm{db}$ mice. Metabolism 51: 901-905, 2002.

19. El Nahas AM, Abo-Zenah H, Skill NJ, et al: Elevated epsilon(gamma-glutamyl) lysine in human diabetic nephropathy results from increased expression and cellular release of tissue transglutaminase. Nephron Clin Pract 97: c108-117, 2004.

20. Sodhi CP, Phadke SA, Batlle D and Sahai A: Hypoxia and high glucose cause exaggerated mesangial cell growth and collagen synthesis: role of osteopontin. Am J Physiol Renal Physiol 280: F667-674, 2001.

21. Yamaguchi H, Igarashi M, Hirata A, et al: Progression of diabetic nephropathy enhances the plasma osteopontin level in type 2 diabetic patients. Endocr J 51: 499-504, 2004. 